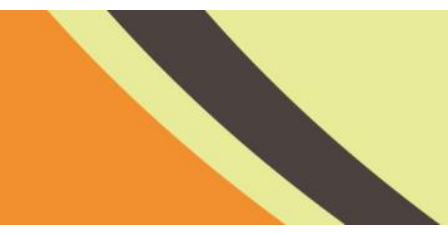

\title{
Capitalistic Transition in Food System and Food consumption in Mae Cham District, Chiang Mai, Thailand
}

\author{
Poon Theingburanathum ${ }^{1}$, Pongtip Thiengburanathum ${ }^{1}$. \\ ${ }^{1 .}$ Chaing Mai University School of Public Policy, Chiang Mai University, 239 Huay Kewa Rd, Chiagn Mai 50200, Thailand \\ Corresponding author: poon@eng,cmu.ac.th, pongtip_t@cmu.ac.th
}

\begin{tabular}{l} 
ARTICLE INFO \\
\hline Article History: \\
Received: July 3, 2019 \\
Final Revision: November 14, 2019 \\
Available Online: December 13, 2019 \\
KEYWORDS \\
\hline Capitalistic Transition, Food System, Food \\
Consumption, \\
CORRESPONDING AUTHOR \\
\hline *E-mail: poon@eng,cmu.ac.th, pongtip_t@cmu.ac.th
\end{tabular}

\section{INTRODUCTION}

\subsection{Research Background}

Mae Cham is a district located 156 kilometres to the south of Chiang Mai, surrounded by national forest as regulated by the Ministerial Regulation No. 712 (BE 2517), published in the Gazette, Vol. 91, No. 225, December 29, 1974. Although the majority of land in Mae Cham is considered as national forest, but Mae Cham has also been recognised as a place with high number of hotspots and burned area in Northern Thailand. The key factors for burning in Mae Cham was to clear the land for rainfed agricultural purposes especially for cash crops, and clear the forest ground cover for forest products scavenging.

This paper looked at the land use change and production output from Mae Cham and how it has changed over the years through statistical analysis of land use covered. The land use change has lead to a second questions, of how the food consumption of the local people in Mae Cham also changed over the years. An in-depth interview with 30 local residents in Mae Cham was conducted to gather information on what they are eating and how the ingredients use in these dishes has changed from the past. The trigger date in this study is 1973, when the first road access to Mae Cham was completed.

The land use between 2000-2013 as shown in Figure 1, shows clearly that the cash crop area in the Northern region has increase by $15 \%$, while the forest area has been reduced by $7.5 \%$. The changes in land use has impacted the natural resources and environment in Mae Cham. The change in land based activities has also impacted livelihood of the local people in Mae Cham. The paper will explore the livelihood in terms of food consumption of the local people.

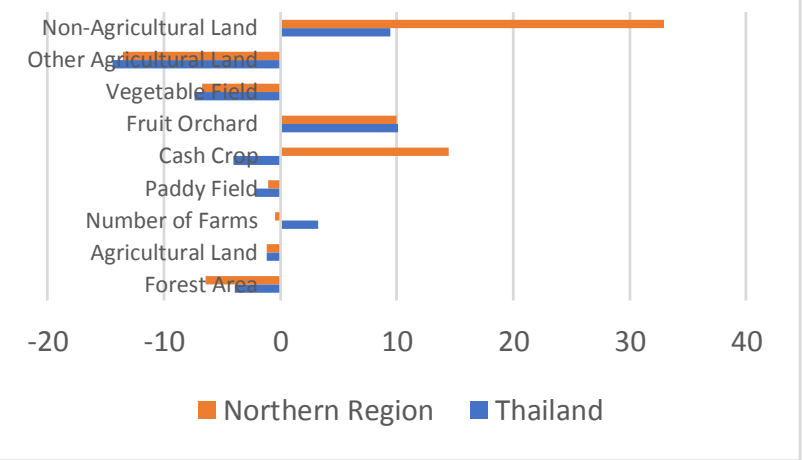

Source: Land Development Department, Ministry of Agriculture and Agricultural Cooperatives.

Figure. 1 Land use change in Northern Region compared to Thailand. 


\subsection{Literature Review}

Mae Cham District covers the total area of 2,657 square kilometer, of which $81 \%$ is classified as national forest. $19.75 \%$ of has other usage, but only $0.75 \%$ of land has land documents. The other $19 \%$ has been occupied and use without land title1. The lack of land titles leads to the lack of ownership and responsibility to use the land sustainably. The $19 \%$ of land has been used mainly for cash crops with the majority being animal feed corn. The corn production land has increase from $138.08 \mathrm{~km}^{2}$ in 2009 to $231.80 \mathrm{~km}^{2}$ in 2013 or increase by $167.87 \%$. The dramatic increase was attracted by the price of maize that has been fluctuating depending on the demand and supply. From January - May the price is low as the it is the harvesting season and large amount of maize are flooded into the market as shown in Fig. 2.

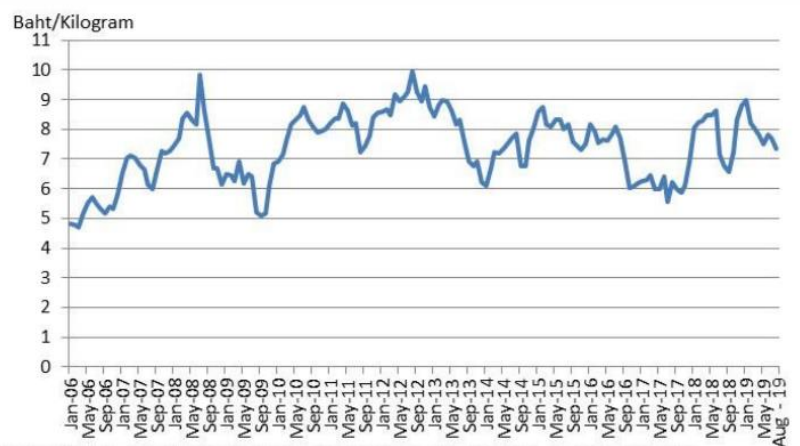

Source: Office of Agricultural Economics, Ministry of Agriculture and Agricultural Cooperatives

Figure. 2 Farm Gate Prices of Maize

The main reasons for farmers to choose maize is because there is credit line available, the farmers may borrow seeds, chemical fertilizer, and other chemicals from the middleman who will deduct the difference from the sell of the maize later on. Maize is also easy to grow, it can be rain fed and does not take much time to grow, hence, maize is able to provide financial security to the farmers who have no land tile or other collaterals to take formal loans from the bank.

The is proved by the agricultural production trend from Mae Cham as shown in Fig. 3 and the top 5 cash crops in Mae Cham in Fig. 4. These figures showed that the animal feed corn production is on an increasing trend while other products are decreasing.

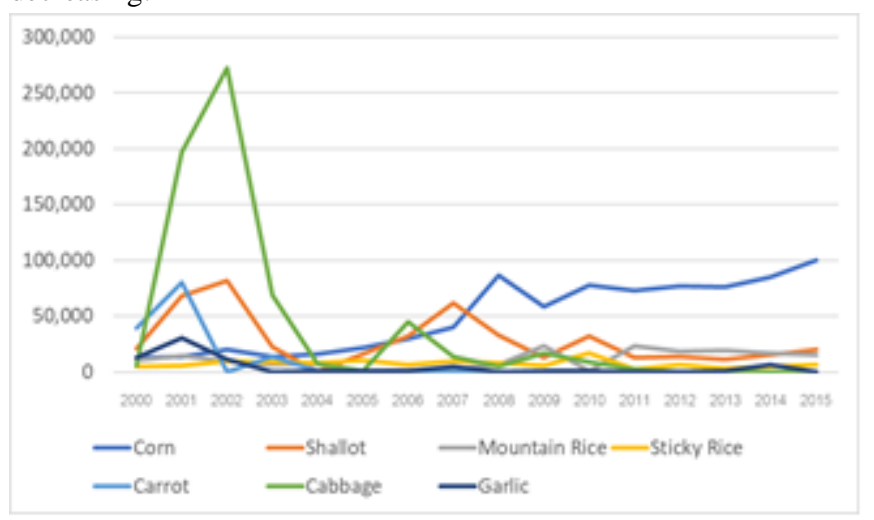

Source: Office of Agricultural Economics, Ministry of Agriculture and Agricultural Cooperatives

Figure. 3 Agricultural Production in Mae Jam District from 2000-2015 (ton of product)

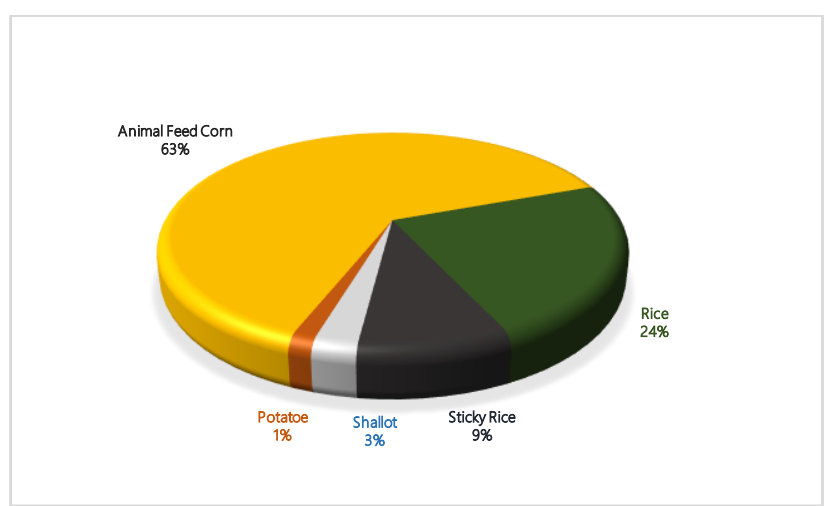

Source: Office of Agricultural Economics, Ministry of Agriculture and Agricultural Cooperatives.

Figure. 4 Top 5 cash crops in Mae Cham 2014-2019

Animal feed corn has become the main products of Mae Cham generating incomes for the farmers. The animal feed corn production also lead to two other activities that on the land. The first one being the use of fire to clear the land before monsoon season to clear the land for the planting season during the monsoon months. The concentration of hotspot or fire detected through satellite images was highest in cash crops plantation area especially during the late February-April as shown in Figure 5.

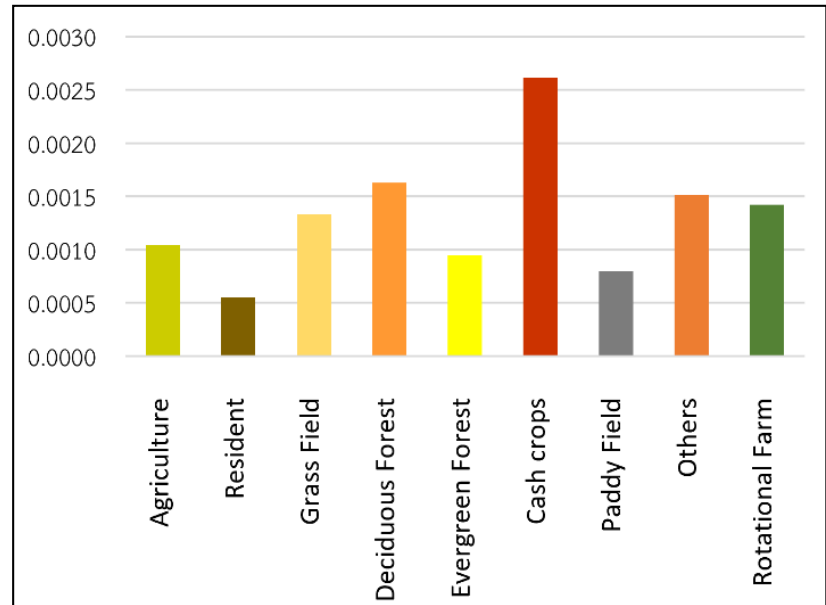

Figure. 5 Hot Spot concentration by land use 2014-2018

The high concentration of hot spot means that the land was on fire. The biomass on the land act as fuel for the fire and emits carbon dioxides as well as other particulate matter especially PM10 and PM 2.5 which contributes to haze during air inversion period in the dry season. Figure 6 showed the location of the cash crops field and areas with high concentration of hotspot spreading all over Mae Cham. 


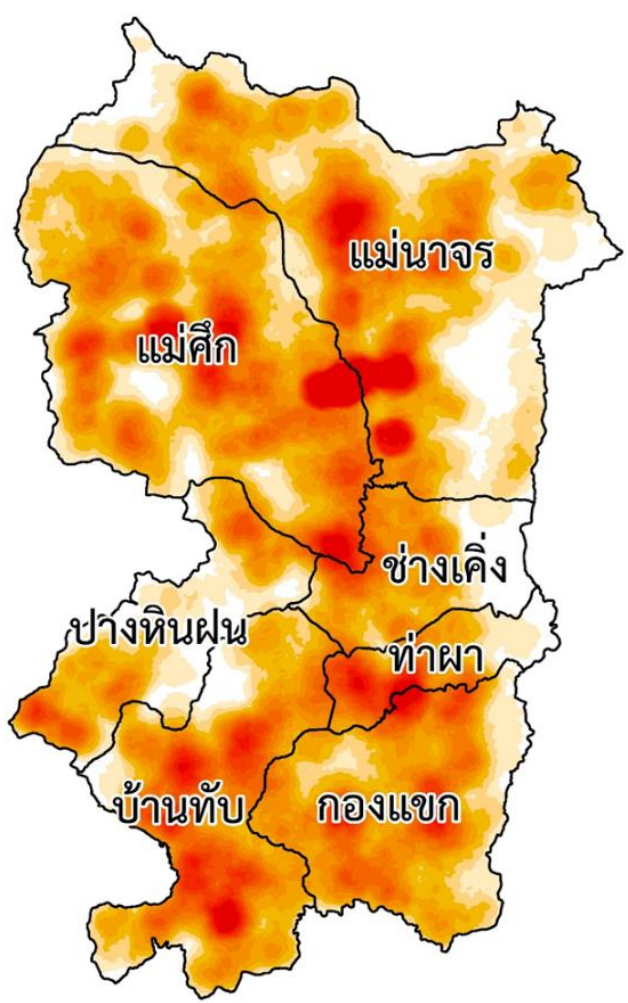

Figure 6. Hot Spot concentration in Mae Cham District, Chiang Mai.

The second impact on land use the increase use of agrochemicals. The amount of chemical applied on the land in Mae Cham is shown in Figure 7. The year with the largest use of agrochemical was in 2013, when the animal feed corn production was also at its peak. The heavy use of agrochemicals not only impact the soil quality but also the health of the farmers. All of the farmers interviewed said that they are suffering from the use of agrochemical such as skin irritation, eyes irritation and difficulty in breathing.

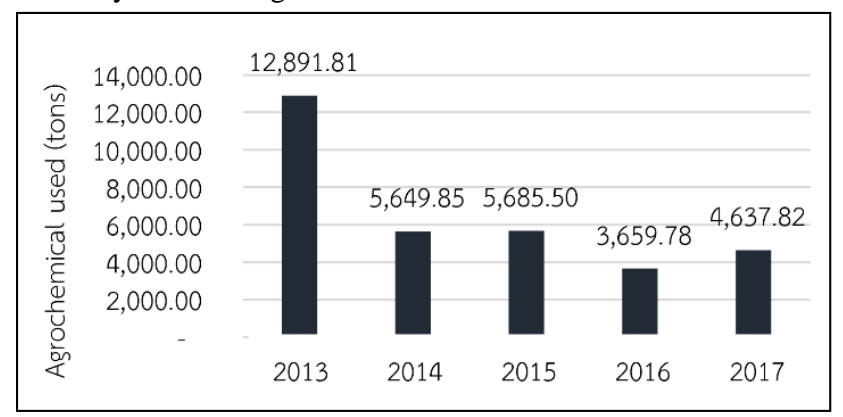

Figure 7. Agrochemical use in Mae Cham 2013-2017

\section{RESULT AND DISCUSSION}

As the activities on the land has changed from rice for family consumption to cash crops to feed into global food system. The livelihood of the people in Mae Cham has changed over the years as well. Not only Mae Cham has become an exporter of agricultural products, Mae Cham also import other food and material such as kerosene, salt, nail, cement, soap, canned fish and milk ${ }^{2}$.

The three main sources of food, rice, vegetable, and meat in Mae Cham come from various sources. Rice is locally produced except in some years where there might be drought or flood that effect the production of rice. Vegetables mainly come from local plantations, bought from the market of scavenged from the forest. And meat could come from scavenging edible insects and animal from the forest or raised locally ${ }^{3}$.

From the interview with 30 household in Mae Cham between 25-28 September 2019. The majority of the respondents were female ( 27 respondents and 3 male respondents) with $63 \%$ being more than 51 years old. 17 of the respondents were farmers. It was found the people of Mae Cham still eat locally produced rice, but the vegetables grown in commercial plantations are sold as wholesale to the middle man who take them to the market in Chiang Mai and not Mae Cham. The vegetables consumed in Mae Cham nowadays either homegrown or both from the market where the seller bought it from Chiang Mai. Meat or main sources of protein now come from outside of Mae Cham, the household livestock are mainly for use in rituals and not for everyday consumption.

The key seasoning ingredient for food in Mae Cham has been salt upto present day. Although dishes such as fermented been paste, cabbage in pork and tamarind soup, stir fry vegetables remain the same as before 1973, but there are other ingredients added to the food such as monosodium glutamate (MSG), fish sauce, seasoning powders, and seasoning cubes as shown in Fig. 8.

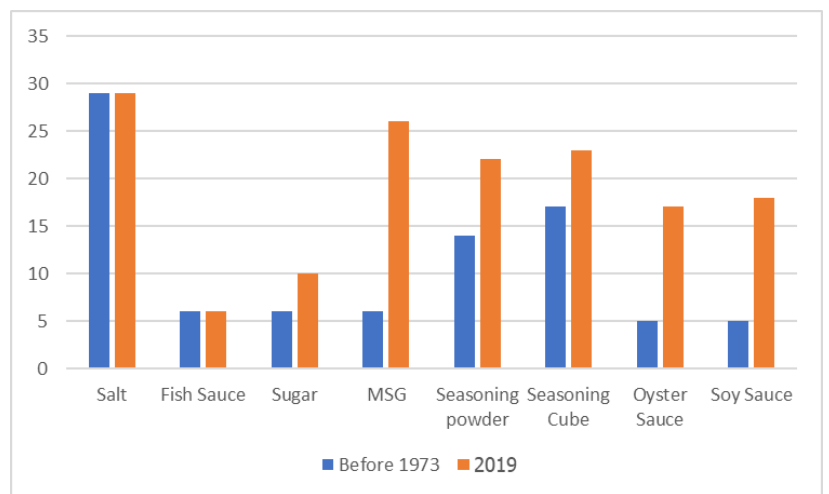

Figure 8. Food seasoning applied to food in Mae Cham's households before 1973 compared to 2019.

Salt is still the main seasoning agent used in cooking food in Mae Cham, and second by MSG 1-2 teaspoons are added when cooking.

Mae Cham population come from a number of ethnicity such as Mong, Pakakayor and Kon Muang (the main local residents). In the past people would find and consume local products such as home grown vegetables or vegetables from the forest. meat would only be consumed during festive times, and it would be either raised locally or hunted from the forest. At present time, both vegetables and meat has become readily available in the market and provide convenience to the people.

There are five popular dishes cook and eat by Mae Cham people from the past to present day: Pak Kad Jor (Chinese Cabbage soup with spare ribs and tamarind), Nam Prik Tou Nao (fermented bean chili paste), stir fried vegetables, fried fish and Kang Kae (mixed vegetable and herbs soup with meat). Nam Prik Tou Nao is the best in terms of nutrition, 1 cup of Nam Prik Tou Nao contained 238 kilo calories, with 17.9 grams of proteins, 27.4 grams of carbohydrate and 8.1 grams of fat, as well as a varieties of vitamins and minerals.

There are more varieties of fish available for local consumption than the past. In the past it was more common to eat small fishes and people still use pork oil for cooking, which contain high content of saturated fat compared to vegetable oil.

Both Kang Kae and stir fry vegetables contains both meat and vegetable and provided the required nutrition for human body. The past and present day Kang Kae and stir fry vegetables provide the same amount of proteins, carbohydrates, fat, vitamins and 
minerals. However, the main difference came from the added seasoning such as fish cause and MSG. Kang Kae cooked before 1973 contained 429 milligrams of sodium compared to 663 milligrams of sodium in the present day Kang Kae. As for stir fried vegetable the dish cooked before 1973 contain 681 milligrams of sodium compared to 2,154 milligrams of sodium in the present day stir fried vegetables. The recommend amount of sodium consumption by Ministry of Public Health is 1,475 milligram per day. The amount of sodium consumed exceeded the recommend amount will put the consumers in the high risk for other sickness such as heart disease, high bold pressure and diabetes.

\section{CONCLUSION}

The access road to Mae Cham has made other food ingredients and seasonings produced elsewhere readily available in Mae Cham. The local food system which previously provide sufficient food for local consumption has been connected to the national and global food system. The output of agricultural products exceeds local demand and has been exported out of Mae Cham. At them same time other food has been imported to Mae Cham for local consumption. The cash that cash crop farmers earned from selling cash crops also allow them to be engaged in the capital market.

The farmers are now able to purchase goods and services from outside of Mae Cham, this include children's higher education, motorcycles, trucks, and electrical appliances. These demands are associated with the mean to become modernised and an aim for better lifestyle that imitates the lifestyle of people in the city.

The expanded agricultural production area caused deforestation. And land clearing with fire has created an transboundary air pollution not only in Mae Cham be also in other areas. The result of fire in the dry season caused haze in Mae Cham and other parts of Chiang Mai as well. The new cycle for food production is illustrated in Fig. 9.

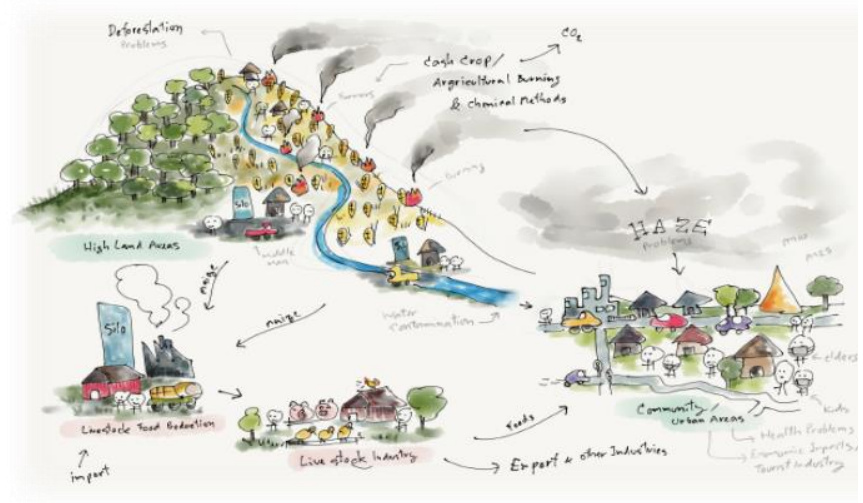

Figure 9. Food system in Mae Cham.
The land transition in Mae Cham has both positive and negative impacts to the people and to the land. The lost of forest area, soil and water contamination from heavy use of agrochemical, high level of air pollution, and health impact from excess use of food additives. The people in Mae Cham are now equipped with purchasing power to assist a more comfortable life and opportunity to access higher education. However, the health of the people, the land and the environment in Mae Cham has borne the cost of the gain in purchasing power.

\section{ACKNOWLEDGMENT}

We would like to thank National Research Council of Thailand for its financial support for Haze Free Thailand Project Phase 2, where the information for this paper was based on.

\section{REFERENCE}

[1] Somkiat Meetham. 2015. Forests and Land Rights in Mae Cham: Problems, Causes, Effects and Solutions. Accessed in March 2018.

[2] Anu Nernhard. 2012. Life in Mae Cham.

[3] Narong Sikhiram, 2018 ; Food Culture in Lanna Way of Life. Journal of Food Health and Bioenvironmental Science $11: 55$ -66 . 